\title{
Türk Eğitim Sisteminin Örgüt Yapısı: Denetim ve Merkezileşme
}

\author{
DOI: 10.26466/opus.607124
}

\author{
Mustafa Çelikten* - Kemal Ayyıldız** - Yeliz Yeni Çelikten*** \\ * Prof. Dr, Erciyes Üniversitesi, Eğitim Fakültesi, Melikgazi / Kayseri / Türkiye \\ E-Posta: celikten@erciyes.edu.tr \\ ORCID: $\quad$ 0000-0001-7966-3912 \\ ** Hasan Polatkan Ortaokulu, Melikgazi/Kayseri /Türkiye \\ E-Posta: kemal.ayyildiz@hotmail.com \\ ORCID: $0000-0002-1652-4226$ \\ *** Keykubat Anadolu İmam Hatip Lisesi, Melikgazi / Kayseri / Türkiye \\ E-Posta: yelizyeni1979@gmail.com \\ ORCID: $\underline{0000-0002-1825-7002}$
}

\section{Öz}

Bu çalışmada Türk Eğitim Sisteminin örgüt yapısı biçimselleşmesi, merkezileşmesi ve denetimi açısından incelenmesi amaçlanmıştır. Ĕ̆itim örgütleri insan merkezli örgütler olduğu için aşırı biçimselleştirilmiş kurallar ve prosedürler kabul görmemektedir. Türk milli eğitim sisteminde zaman zaman biçimselleştirmeye yönelik girişimler olsa da süreç içerisinde esnemeler olduğu görülmektedir. Özellikle yönetsel açıdan bakıldığında resmi iş ve işlemlerin belli prosedürler yerine getirilmek suretiyle uygulanmaya başlandığı söylenebilir.Örnek vermek gerekirse kurumların resmi yazışmalarda izleyeceği yol ve yöntemler en ince ayrıntısına kadar Bakanlık tarafindan belirlenmektedir. Yetkinin kullanılması açısindan bakıldığında yetkinin örgütün üst kademelerinde toplandığ ve alt kademelere devredilmediğ $i$ örgütler merkezileşme derecesi yüksek örgütler, yetkinin alt kademelere devredildiği örgütler ise merkezileşme derecesi düşük örgütler olarak adlandırılır. Örgütlerde merkezileşme derecesini kararlara katılım ve yetki kademesi olmak üzere iki temel ölçüt belirlemektedir. Kararlara katılım, çeşitli kademelerdeki çalışanların örgüt kaynaklarının dağıtımı ve örgüt politikalarının belirlenmesi gibi örgütün bütününü ilgilendiren konulardaki kararlara katılım derecesidir. Belirli amaçlara ulaşmak amacıyla kurulan örgütlerin, amaçlara ulaşma düzeyini belirlemek için denetime yer verilmektedir. Denetim kavramının birçok tanımı bulunmaktadır. Yapılan tanımlarda denetimin değişik yönlerine vurgu yapılmaktadır. Bir görevin yolunda gidip gitmediğini anlamak için yapılan araştırma; kamu yararına davranışı kontrol etme süreci; örgütlerde kabul edilen amaçlar doğrultusunda, belirlenen kurallara uygun olup olmadığgnın anlaşılması süreci şeklinde denetimin farklı tanımları bulunmaktadır.

Anahtar Kelimeler: Hiyerarşi, Merkezileşme, Uzmanlaşma, Denetim. 


\title{
Organizational Structure of Turkish Education System: Inspection and Centralization
}

\begin{abstract}
In this study, it is aimed to examine the Turkish Education System in terms of organizational structure, centralization and inspection. Over-stylized rules and procedures are not accepted because educational organizations are human-centered organizations. Even though there are attempts to formalize the Turkish national education system from time to time, it is seen that there are stretchings in the process. From a managerial point of view, it can be said that formal works and transactions have started to be implemented by performing certain procedures. Particularly from the administrative point of view, it can be said that formal works and transactions have started to be implemented by performing certain procedures. In terms of the use of authority, organizations where authority is concentrated in the upper echelons of the organization and not transferred to lower echelons are called organizations with high degree of centralization, and organizations where power is transferred to lower echelons are called lowlevel organizations. The degree of centralization in organizations is determined by two basic criteria: participation in decisions and level of authority. Participation in decisions is the degree to which employees at various levels participate in decisions concerning the organization as a whole, such as the distribution of organizational resources and the determination of organizational policies.
\end{abstract}

Keywords: Hierarchy, Centralization, Specialization, Inspeciton. 


\section{Giriş}

Türk eğitim sisteminin günümüzdeki yapılanması, 3 Mart 1924'te yürürlüğe giren ve ülkedeki tüm eğitim kurumlarının Milli Eğitim Bakanlığ eliyle devlet kontrolü altına alınmasını öngören düzenlemeye dayanır. Öğretimin birleştirilmesini amaçlayan 1924 tarihli Tevhid-i Tedrisat Kanunu ile Türk Eğitim Örgütlerinin yapı ve işlevlerinde önemli değişmeler yaşanmıştır (Can ve Çelikten, 2000). Tevhid-i Tedrisat (öğretim birliği) adını taşıyan bu yasal düzenleme ile çoğulculuğa dayanan tüm eğitim kurumları kaldırılarak tüm aşamaları devlet tarafından belirlenen bir eğitim modeline geçilmiştir. Bu model, devlet eliyle eğitim yapılması düşüncesinden daha ileri giderek devlet dışı organizasyonların gerçekleştirmiş olduğu her türlü eğitim faaliyetini de yasaklamıştır. Merkeziyetçiliğe dayanan bu yapıda tüm düzenlemeler Milli Eğitim Bakanlığı tarafından yapılır ve ülkenin tüm okullarında gelişmeler yetenek, ihtiyaç ve beklentiler gözetilmeden aynı şekilde uygulanır (Başdemir, 2012).

Cumhuriyetin ilanından günümüze değin Türk Eğitim Sisteminin örgüt yapısı "merkezi" yönetim odaklı bir örgüt yapısı olagelmiştir. Cumhuriyetin kurulmasıyla birlikte eğitim yönetiminde tüm yetkilerin merkezde toplandığ1 görülmektedir. Tarihsel Süreç İçinde Milli Eğitim Bakanlığı: 1923'ten 27 Aralık 1935 tarihine kadar "Maarif Vekâleti", 28 Aralık 1935'ten 21 Eylül 1941 tarihîne kadar "Kültür Bakanlığı", 22 Eylül 1941'den 9 Ekim 1946 tarihine kadar "Maarif Vekilliği", 10 Ekim 1946'dan sonra "Millî Eğitim Bakanlığı", 1950'den sonra "Maarif Vekâleti", 27 Mayıs 1960 tarihinden sonra "Millî Eğitim Bakanlığı" adıyla çalışmalarını sürdürmüştür. Okullarda yönetim basamakları kısa iken MEB'in yönetim basamakları uzundur. Bakan yönetim kademesinin en tepesinde bulunur ve kendisine doğrudan bağlı olan Yükseköğretim Kurulu (YÖK) özel kalem müdürlügü şeklinde görülen başkanlıkları ve müşavirlikleri yönetir. Diğer birimler ise müsteşara, müsteşar bakan yardımcısına, bakan yardımcısı da bakana bağlıdır. Dolayısıyla bakanın bir kararının kendisine doğrudan bağlı olmayan birimlere ulaşması için epey yol kat etmesi gerekmektedir. Örneğin bakanın aldığı bir karar sırasıyla bakan yardımcısı, Milli Eğitim Sisteminin Örgütsel Yapısı ve Maarif Müfettişleri Alt müsteşar, il milli eğitim müdürlüğü, ilçe milli eğitim müdürlügü ve okul müdürlüğüne ileti- 
lerek bir öğretmene ulaşmaktadır. Bu arada il, ilçe ve okul müdürlüklerinde de hiyerarşilerin olduğu göz ardı edilmemelidir. Bakanlığın taşra ve yurtdışı teşkilatları dışında kalan birimler merkez teşkilatını oluşturmaktadır (Çelikten, 2003; Bozkuş, 2016).

Türkiye'de bütün eğitim kurumları Tevhid-i Tedrisat Kanunu (1924) ile bugünkü adı ile Milli Eğitim Bakanlığı (MEB) çatısı altında toplanmıştır. Sonraki dönemlerde gelişen ve değişen koşullara eğitim sistemimizin adaptasyonunun sağlanması amacıyla kanun hükmünde kararname, tüzük, yönetmelik, yönerge ve genelgeler yayımlanmıştır. Son olarak 14.09.2011 tarihli Resmi Gazete'de yayımlanan 652 sayılı Kanun Hükmünde Kararname (KHK) ile MEB Teşkilat Yapısı yeniden yapılandırılmıştır. Bu sayede işlevselliğini yitirmiş birimler kaldırılmış, aynı ya da benzer işi yapan birimler birleştirilerek merkez teşkilatı daha dinamik bir yapıya kavuşmuştur (Özkan ve Çelikten, 2017). Böylece Bakanlığın üzerindeki gereksiz bürokrasi azaltılmış, karar alma ve uygulama süreçleri daha hızlı hale gelmiştir.

\section{Biçimselleşme}

Örgütsel yapının diğer bir unsuru olan biçimselleşme (formalization) iş yapış şeklinin; kurallar, düzenlemeler, politikalar ve prosedürler tarafından şekillendirilmesi ve sınırlanma derecesi olarak tanımlanabilir. Literatüre ilişkin yakın tarihe bakıldığında; Duncan (1976) biçimselleşmeyi bir derece olarak değerlendirmekte ve örgüt içerisinde görevler yerine getirilirken önceden tanımlanmış belirli usul, yöntem ve ilkelerin kullanılmasına ne derece ağırlık verildiğinin bir ifadesi olduğunu belirtmektedir (Koçel, 2010). Benzer bir biçimde Daft (2010) biçimselleşmenin örgüt içerisinde yazılı belgelerin miktarına ilişkin bir kavram olduğunu belirtmekte ve yazılı dokümantasyon süreçleri, iş tanımları, yönetmelik ve iş yeri kurallarını gösteren kitapçıkları içerdiğini aktarmaktadır. Daft, bu yazılı dokümanların davranış ve eylemleri tanımladığını belirtirken; Koçel (2010) biçimselleşmeyi daha da ayrıntılı bir şekilde ele alarak, neyin ne zaman, nerede, nasıl ve kim? tarafından yapılacağını önceden ayrıntılı olarak belirlenmiş olmasının ve bunlara uyulması zorunluluğunun getirilmiş olması biçiminde tanımlamaktadır. Biçimselleşme en iyi deneyimlerin örgütsel hafızaya aktarılmasına imkan tanımakta, bilginin verimli kullanılışı 
doğrultusunda performansa özellikle de kıymetli bilginin toplanması ve öncelikler ile değerlerin iletimi aracılı̆̆ıyla hizmet ederek pozitif etki sağlamaktadır (Chatzoglou vd., 2011).

Tolbert ve Hall (2016)'e göre biçimselleşme iki ucu keskin bir bıçak gibidir ve biçimselleşmenin olası olumsuz sonuçları da bulunmaktadır. Yüksek derece biçimselleşme, yöneticileri, çalışanlarını kontrol altına alabilmek için daha açık kurallar aramaya yönlendirirken yöneticilerin zorunlu kuralların ötesinde çalışanların davranışlarını etkileme becerisini s1nırlandırmaktadır. Dolayısıyla kurallara bağlı ve katı örgütlerde müşteri taleplerine, arzda doğabilecek değişikliklere ve diğer zorluklara karşı baş edebilecekleri neredeyse hiç esneklik bulunmamaktadır. İronik olarak, çalışanların davranışlarını kontrol altına almak için koyulan kurallar, onlara yöneticilerin direkt denetiminden özerklik sağlamaktadır. Bir diğer dezavantaj ise kural koyucular tarafından sezinlenemeyen bir problem ile karşılığında çalışanların probleme karşı etkin tepki verebilmesini yüksek derece biçimselleşmenin engellemesidir. Uyulması gerekli kurallar iş süreçlerini örgüt için verimli olmayan yollar aracılığıyla yavaşlatmaktadır (Özdemir, 2016).

Eğitim örgütleri insan merkezli örgütler olduğu için aşırı biçimselleştirilmiş kurallar ve prosedürler kabul görmemektedir. Türk milli eğitim sisteminde zaman zaman biçimselleştirmeye yönelik girişimler olsa da süreç içerisinde esnemeler olduğu görülmektedir. Özellikle yönetsel açıdan bakıldığında resmi iş ve işlemlerin belli prosedürler yerine getirilmek suretiyle uygulanmaya başlandığı söylenebilir. Özellikle birçok iş ve işlemin yönetmelik ve yönergelerle düzenlenmeye çalışılması bunun göstergesidir. Örnek vermek gerekirse kurumların resmi yazışmalarda izleyeceği yol ve yöntemler en ince ayrıntısına kadar Bakanlık tarafından belirlenmektedir. Benzer şekilde öğrencilerle ilgili disiplin işleri, sınıf geçme ve devamsızlık işleri gibi birçok konu biçimselleştirilmiş usullerle yerine getirilmektedir.

\section{Merkezileşme}

Bazı örgütlerde yöneticilerin örgütle ilgili tüm kararları aldıkları, alt kademe yöneticilerinin ise üst yönetimin talimatlarını yerine getirdikleri 
ifade edilebilir. Bu tür örgütlerin merkezcil bir yapıya sahip oldukları kabul edilirken; bazı örgütlerde, karar alma yetkisinin faaliyetlere yakın olan yöneticilere bırakılması ise, yerinden yönetim olarak kabul edilmektedir. Merkezcil yönetim, karar alma yetkisinin örgütün üst kademelerinde toplanmasın ifade etmektedir. Yerinden yönetim ise, karar alma yetkisinin örgütün alt kademelerine doğru yayılımına dayanmaktadır (Efil, 2002).

Koçel (2010), merkezileşme derecesinin organizasyondaki karar verme yetkisinin kademeler arasındaki dağıtımı ile ilgili bir mevzu olduğunu belirmektedir. Eğer bu yetki alt kademelere doğru kaydırılırsa merkeziyetçi, merkezileşmemiş (merkezkaç) bir organizasyondan, aksine karar yetkisi üst kademelerde toplanırsa merkezi bir organizasyonda söz edilecektir. Konuyu kararlara katılım yönünden ele alan Aldemir'e göre (1985) eğer bir örgütte tüm kararlar üst yönetimce alınıyorsa ve alt kademedeki personellerin kararlara katılmalarına izin verilmiyorsa o örgütün merkezi bir yapıya sahip olduğundan söz edilebilir. Bu durumun tam aksi bir şekilde alt kademelerde bulunan işgörenler karar sürecine etki edebiliyorsa ve kararlara katkıda bulunacak bir pozisyona sahip ise o örgüt için ademi merkezi(merkezin yokluğu) yapıdan söz edilebilir.

Kararların merkezden alındığ dıkça daha uygun kararların alınacağı kanaati hâkim olmaktadır. Bu önerme aslında merkezileşme derecesiyle ilgili bir durumdur ve organizasyonlarda karar verme yetkisinin kademeler arasında dağılımı ile ilgilidir (Baransel, 2010). Karar verme yetkisinin merkezileşmesi, diğer bir ifade ile üst kademelere kaydırılması (ademi merkeziyetçi olmayan yapı) karar alınırken katılımcılığı ortadan kaldıracaktır (Aldemir, 1985). Nitekim Worthy (1950) merkezileşmenin aşırıya kaçtığı örgütlerde çalışanların takdir yetkilerinin nispeten az olduğuna vurgu yapmaktadır (Tolay, 2013). Merkeziyetçi yapının yüksek olduğu örgütlerde daha fazla işgörenin karar sürecine katkı sağlaması ile örgüte ilişkin sorunlar farklı bakış açılarıyla ele alınabilecektir (Robbins, 1998; Aldemir, 1985). Bu nedenle merkeziyetçi yapının yüksek düzeyde olması, alt kademedeki işgörenlerin örgütsel konu ve sorunlara ilişkin kendi değerlendirmelerini ortaya koyabilmelerine imkân sağladığı için yapısal bağlamda oluştuğu düşünülen sessizlik olgusunu ortadan kaldıran bir durum olarak değerlendirilmektedir. 
Yetkinin kullanılması açısından bakıldığında yetkinin örgütün üst kademelerinde toplandığı ve alt kademelere devredilmediği örgütler merkezileşme derecesi yüksek örgütler, yetkinin alt kademelere devredildiği örgütler ise merkezileşme derecesi düşük örgütler olarak adlandırılır. Örgütlerde merkezileşme derecesini kararlara katılım ve yetki kademesi olmak üzere iki temel ölçüt belirlemektedir. Kararlara katılım, çeşitli kademelerdeki çalışanların örgüt kaynaklarının dağıtımı ve örgüt politikalarının belirlenmesi gibi örgütün bütününü ilgilendiren konulardaki kararlara katılım derecesidir (Erserim, 2011).

\section{Uzmanlaşma}

Pugh, Hickson, Hining ve Turner (1968)'e göre uzmanlaşma, pozisyonlar arasında resmi görevlerin dağıtılması ve örgüt içindeki işbölümüyle ilgili bir kavramdır. İşbölümü, örgütsel faaliyetlerin farklı kişiler tarafından yerine getirilmek üzere farklı işlere ayrılma derecesini ifade etmektedir. İşbölümü geniş ölçüde uygulandığında, çalışanların tek bir görev alanında uzmanlaştı̆̆ görülmektedir (Efil, 2002). Bu açıdan bakıldığında iş bölümünün zorunlu olarak uzmanlaşmayı gerektirdiği söylenebilir.İş bölümü veya iş uzmanlaşması, görevlerin ne derece alt işlere bölünmüş olduğunu tanımlamaktadır (Robbins, 1998; Daft, 2010). Uzmanlaşmanın özünü, bir dizi adıma bölünen işin her bölümünün ayrı kişiler tarafından yapılması oluşturmaktadır (Robbins, 1998). Böylece kişiler işin tümünü yapmaktan ziyade belirli bir kısmı üzerinde uzmanlaşmaktadırlar (Robbins ve Judge, 2013). Bunu uzmanlaşmanın derecesine bağlayan Daft'a göre (2010), eğer uzmanlaşma yoğunluğu yüksek ise kişiler görevin dar bir kısmını yerine getirecektir. Tersi durumda ise kişi işin daha geniş bir bölümünü veya tamamını yerine getirecektir. Diğer bir ifade ile iş ne kadar parçalara ayrılmışsa iş bölümünün dolayısıyla da uzmanlaşmanın artacağ lir. Bu açıdan bakıldığında çok az göreve sahip bir işgörenin daha fazla uzmanlaşmış bir işi olduğu sonucuna ulaşılabilmektedir (Aldemir, 1985).

Milli Eğitim Bakanlığı yapılanması içerisinde 2012 yılında 652 sayılı KHK hükümlerine dayanılarak; (a) Bakanlığın görev alanına ilişkin olarak politika, strateji ve hedeflerin tespiti maksadıyla araştırma ve incelemeler yapmak, (b) Uluslararası kurum ve kuruluşlar nezdinde yapılacak ve Bakanlıkça uygun görülecek toplantı ve çalışmalara katılmak ve (c) Eğitim 
sistemleri ve uygulamaları konusunda çalışmalarda bulunmak, yeni stratejiler geliştirmek, Bakanlığın hizmet kapasite ve kalitelerinin artırılmasına yönelik çalışmalar yapmak, hazırlanmakta olan çalışmalara katılmak, eğitim sistemleri ve uygulamaları konusunda ulusal ve uluslararası çalışmaları takip etmek ve Türkiye'de uygulanabilir metotlar üzerinde çalışmalarda bulunmak amacıyla Milli Eğitim Uzmanlığı kadrosu oluşturulmuştur. Milli eğitim uzmanlığı kadrosunun oluşturulmasıyla Bakanlık çalışmalarında uzmanlaşmaya önem verildiği görülmektedir.

\section{Standartlaşma/Standardizasyon}

Standartlaşma, sürekli şekilde tekrarlanan işler ya da sürekli şekilde karşılaşılan sorunların çözümü için belirlenen kurallardır (Aldemir, 1985) . Kurallar, arzulanan amaçlara ulaşmak için gerekli yöntemleri gösteren, resmi ve yazılı ifadelerdir. Yazılı kurallar ve standart çalışma yöntemleri, örgüt içindeki davranışların kontrol edilmesine yardımcı olmaktadırlar. Örgütler, çalışanlarına örgütsel görevlerini nasıl yapacaklarını göstermekte, onlara görevleri ile ilgili yetki ve sorumluluk vermektedirler (Jones, 2004). Robbins (1990) ise bürokratik örgüt yapısının kilit kavramının standartlaşma olduğunu ve standartlaşma ile birlikte iş süreçlerinde etkin bir kontrol ve koordinasyon sağlanabileceğini belirtmektedir. Bu yönü ile standartlaşma örgütün her biriminin diğer birimlerin işleyiş̧ine ilişkin uygun yollardan işlemlerini gerçekleştirdiklerini garanti etmektedir (Tolay, 2013).

Eren (1998) standartlaşma derecesinin düşük olması durumunda yöneticilerin işe ve astların kontrolüne yönelik daha fazla zaman ayıracaklarını, aksi takdirde denetim alanının genişleyerek tersi bir durum yaşanacağını belirtmektedir. Çünkü standartlaşma, belirliliği arttırdığından denetim alanının genişlemesine neden olurken, üstlerin astlarına ayıracakları zamanın miktarını da etkilemektedir. Bu bağlamda denebilir ki standartlaşma derecesine bağlı olarak ast üst sözlü iletişimi olumsuz etkilenmektedir. Zira denetim alanının daralması yöneticilerin iş ve astlara daha fazla zaman ve enerji harcamalarını zorunlu kılmaktadır. Bu durum ilişkilerin sıklaşmasına ve belirli konu ve/ veya sorunlara ilişkin daha fazla istişare yapılması gerekliliğini ortaya çıkarmaktadır. 
Milli Eğitim Bakanlığında standardizasyon çalışmalarına örnek olarak İlköğretim Kurum Standartları Sistemi (IKS) verilebilir. Kurum Standartları Sisteminin oluşturulması çalışmaları Kasım 2007'de başlamıştır. 05/11/2009 tarihinde yayımlanan 83 sayılı Genelge ile İKS sisteminin gerekçesi, amacı ve sistemin yapısına yer verilerek ilk kez uygulamaya dair duyurusu yapılmıştır. İlköğretim Kurumları Standartları (IKS); Millî Eğitim Bakanlığına bağlı ilköğretim okulları ile ilçe, il ve merkezi düzeyde, okulda çocuğa yönelik sunulan her türlü hizmete ilişkin verilerin toplanmasına ve gerekli planlamaların yapılmasına kaynak oluşturacak bir iç denetim ve öz değerlendirme sistemidir. İKS, okullarda belirlenen alanlardaki mevcut durumlarının tespit edilmesi, olması gereken durum ile farkın ortaya konulması ve devamında okulların taşıması gereken özelliklerine ulaştırılması amacıyla gerek duyulan geliştirici faaliyetlere kaynak oluşturabilmesi amacıyla yapılan bir çalışmadır. Kurum Standartları Sistemi, eğitim öğretim alanındaki ulusal ve uluslararası gelişme ve yönelimler de dikkate alınarak öncelikle öz değerlendirme (iç değerlendirme) mantığı üzerinden tasarlanmıştır.

\section{Yetki ve Yetki Hiyerarşisi}

Yetki kavramı kurumlaşmış güç, gücün dış gösterisi, başkalarının davranışını etkileyecek kararlar alabilme gücü, yöneticinin karar verme hakkı, itaat istemek hakkı, bir iletişim akımı gibi biçimlerde tanımlanmıştır (Bursalıoğlu, 2000). Yetki hiyerarşik bir yapı içinde, biri üst diğeri ast durumunda olan iki görevli arasındaki bir ilişkidir. Üst, ast tarafından kabul edileceği beklentisiyle kararları tasarlar, biçimlendirir ve asta aktarır. Ast, bu kararlara uyması, kararlara uygun davranış göstermesi gerektiğine inanır. Yetkiyi kullanma hakkına sahip kişi, ne yapılacağını ve kim tarafından yapılacağını bilir. Son söz onundur. Yetkinin sınırları içinde olan durumlarda uygun gücü kullanabilir (Aydın, 1986).

Örgütler büyüdükçe, bütün işleri tek bir yöneticinin yerine getirmesi mümkün olmayacaktır. Dolayısıyla bu tür işlerin yöneticiler arasında paylaşılması gerekecektir. Bunu sağlayan yol da yetki devridir. Karar verme, yürütme, örgütü amacına ulaştırmak için başkalarının eylemlerini isteme gibi hakları kullanmak konusunda üstlerin astlara izin vermelerine, yetkinin delegasyonu veya yetki devri (yetki göçerilmesi) adı verilmektedir 
(Alpugan, Demir, Oktay ve Üner, 1997). Yetki devri, yetkinin bağımsız olarak hareket edebilecek bağımsız bir birime devredilmesidir (Hanson, 1996). Bu yüzden yetki devri kavramı, astların üst basamakların onayını almadan kendi başlarına karar verebilmeleri anlamını ifade etmektedir. Bir örgütte eğer tüm kararlar tepe yöneticisi tarafından veriliyorsa, o örgüt merkeziyetçidir. Kararlar ne kadar çok astlar tarafından üstlerine danışımadan verilebiliyorsa, o örgüt o kadar çok yetki devretmiş sayılır. Yetki devrinin doğal sonucu olan merkezi yetki yapısının tersi, yerinden yönetim tipi (adem-î merkeziyetçi) bir yapıdır. Yetki devri, profesyonel yöneticilerin yetişmesine katkıda bulunur. Bu sayede hem yöneticilerin karar verebilme yetenekleri gelişir, hem de başarılarını gösterebilmelerine imkân tanınmış olur (Aldemir, 1985).

Yetki devri, yönetsel kaynakların en etkin bir şekilde kullanılmasını sağlamaya yönelik önemli bir araç olarak görülmektedir. Örgütlerde işlerin çokluğu ve karmaşıklığı sebebiyle, yöneticilerin zamanlarının büyük bir kısmı detaylarla uğraşmakla geçmektedir. Bu durum ise, örgütlerin daha fazla önem arz eden işlerine yöneticilerin yeteri kadar zaman ayıramamalarıyla sonuçlanmaktadır. Yetki devrinin etkin bir şekilde gerçekleştirilmesiyle, yöneticilerin iş yükleri daha çok hafifleyebilir ve zamanlarını daha verimli kullanabilirler (Erdoğmuş, 1997).

Eğitimde yetki devri, öğretmenin performansını ortaya koyabilme ve kendi potansiyelini kullanabilmesi açısından önemlidir. Goyne, Padgett, Rowicki ve Triplitt (1999) öğretmenlerin sahiplik duygusu ve işlerine bağlılık hissetmeleri için önemli bir kavram olan yetkilendirmeyi, iş doyumunun, motivasyonun ve bağlılığın artmasına, iletişim, karar verme ve kalitenin daha iyi hale gelmesine yardımcı olmak biçiminde de ifade etmişlerdir. Yetkilendirme okul paydaşlarına, kendi gelişimlerinin sorumluluğunu alabilmelerini, kendi problemlerini çözebilmelerini ve bu sayede özerklik, sorumluluk, seçim ve otorite elde etme olanaklarını sağlamaktadır. Bir kurumda yetkilendirme yaklaşımının uygulanabilmesi için öncelikle çalışanlar yaptığı işin amaçlarının bilincinde olmalı, ast ve üstlerine inanmalı, kendi yeteneklerinin farkında olmalı ve yetenekleri ile ilgili fırsatları değerlendirebilmelidirler. Eğer bir okul, öğretmeninin kararlarını destekler, görüşlerini alır ve fikirlerine özen ve saygı gösterirse öğretmen risk almada kendini güçlü görecek, yaratıcllığı gelişecek ve daha olumlu kazanımlar sağlayabilecektir (Araç, 2009). İlköğretim okulu yöneticileri 
kendilerine yasa ve yönetmeliklerle verilen ve sınırları çizilen görevlerini yerine getirirken yine kendilerine yasa ve yönetmeliklerle verilen ve sınırları çizilen yetkilerini kullanırlar (Aydın, 2005; Taymaz, 1997).

\section{Denetim}

Literatürde "denetim" ve "teftiş" kavramlarının bazen eş bazen de farklı anlamda kullanıldığı görülmektedir. Başaran'a göre (2000) denetim, planlanan örgütsel amaçlardan sapmayı önlemek için, örgütün işlemesini izleme ve düzeltme sürecidir. Sullivan ve Glanz'e göre (2000) ise denetim, öğretmenlerin öğrenci başarısını yükseltmek ve öğretimi geliştirmek amacıyla öğretimsel diyaloga katılması sürecidir. Denetim, örgütsel eylemlerin kabul edilen amaçlar doğrultusunda, saptanan ilke ve kurallara uygun olup olmadığının anlaşılması sürecidir. Denetimin temel amacı, örgütün amaçlarının gerçekleştirilme derecesini saptamak, daha iyi sonuç alabilmek için gerekli önlemleri almak ve süreci geliştirmektir. Bu amaçla örgütsel işleyiş bir bütün olarak, planlı ve programlı bir biçimde sürekli olarak izlenir, eksik yönler saptanır, düzeltilir; hataların yinelenmesi engellenmeye ve sağlıklı bir işleyiş gerçekleştirilmeye çalışılır Denetim ve gözetim hizmeti devredilemez ve başka bir sektöre sipariş edilemez bir kamu görevidir (Aydın, 1986).

Belirli amaçlara ulaşmak amacıyla kurulan örgütlerin, amaçlara ulaşma düzeyini belirlemek için denetime yer verilmektedir. Denetim kavramının birçok tanımı bulunmaktadır. Yapılan tanımlarda denetimin değişik yönlerine vurgu yapılmaktadır. Eğitim sisteminde denetim için, kontrol, inceleme, soruşturma, irşat, muayene ve murakabe kavramları kullanılmaktadır. Bir görevin yolunda gidip gitmediğini anlamak için yapılan araştırma; kamu yararına davranışı kontrol etme süreci; örgütlerde kabul edilen amaçlar doğrultusunda, belirlenen kurallara uygun olup olmadığının anlaşılması süreci şeklinde denetimin farklı tanımları bulunmaktadır (Aydın, 2005; Bursalığlu, 2000).Tüm örgütlerde olduğu gibi eğitim örgütlerinde de etkililiğin sağlanması ancak planlanan ve ulaşılan durum arasındaki farkın saptanması, bunun sonucunda da eğitim-öğretim çalışmalarının geliştirilmesi ile mümkün olabilecektir. “Örgütün amaçlarına ne ölçüde ulaştığı, kaynaklarını ne derecede etkili kullanabil- 
diği ve hizmet sürecinin nasıl geliştirilebileceği" gibi soruların yanıtlanabilmesi için eğitim-öğretim sürecinin denetlenmesi ve değerlendirilmesi gerekmektedir. Bu nedenle denetim, eğitim sistemlerinin vazgeçilmez bir süreci olagelmiştir (Demirkasımoğlu, 2011). Denetimi gerekli kılan en önemli unsur, yönetim literatüründe "entropy" olarak bilinen örgütün güç kaybetmesini önlemektir (Aydın, 2005). Etkili bir denetim, kurumdaki sorunların çözümü için de bir anahtar işlevi görerek niteliğin artırılmasını sağlar (Lillis, 1992).

Milli Eğitim Bakanlığındaki denetim sistemine bakıldığında; 14.9.2011 tarihinde yayımlanan 652 sayılı Millı̂ Eğitim Bakanlığının Teşkilat ve Görevleri Hakkında Kanun Hükmünde Kararname ile Bakanlığın teşkilat yapısı yeniden düzenlenmiş, Teftiş Kurulu Başkanlığı kaldırılarak yerine Rehberlik ve Denetim Başkanlığı Kurulmuş, böylece Bakanlığın hizmet birimleri arasında yerini almıştır. Kanun Hükmünde Kararnamenin 17. maddesinde Rehberlik ve Denetim Başkanlığının görevleri ayrıntılı olarak belirtilmiş, bu görevler arasında "Bakanlık teşkilatı ile Bakanlığın denetimi altındaki her türlü kuruluşun faaliyet ve işlemlerine ilişkin olarak, usulsüzlükleri önleyici, eğitici ve rehberlik yaklaşımını ön plana çıkaran bir anlayışla, Bakanlığın görev ve yetkileri çerçevesinde denetim, inceleme ve soruşturmalar ile Bakanlık teşkilatı ile personelinin idarî, malî ve hukukî işlemleri hakkında denetim, inceleme ve soruşturma yapma" işlevi de yer almış, bu arada müfettiş unvanı kaldırılarak Millî Eğitim Denetçisi unvanı verilmiştir.

14.03.2014 tarihli 6528 sayılı Millî Eğitim Temel Kanunu İle Bazı Kanun ve Kanun Hükmünde Kararnamelerde Değişiklik Yapılmasına Dair Kanun ile yapılan değişiklikler sonucunda Millî Eğitim Denetçiliği ve İl Eğitim Denetmenliği unvanları Maarif Müfettişi unvanıyla birleştirilmiş ve Rehberlik ve Denetim Başkanlığında görev yapan Millı̂ Eğitim Denetçileri İl Millî Eğitim Müdürlükleri bünyesinde oluşturulan Maarif Müfettişleri Başkanlıklarına atanmıştır. 652 sayılı Millî Eğitim Bakanlığının Teşkilat ve Görevleri Hakkında Kanun Hükmünde Kararname ile Rehberlik ve Denetim Başkanlığına verilen görevlerin yerine getirilmesi amacıyla Başkanlıkta Maarif Müfettişleri görevlendirilmesi yapılmıştır (MEB, 2018). Milli Eğitim Bakanlığı Teftiş Kurulu Başkanlığı, Bakanın emri veya onayı üzerine aşağıdaki görevleri yapmaktadır (MEB, 2018): 
a) Bakanlığın görev alanına giren konularda Bakanlık personeline, Bakanlık okul ve kurumlarına, özel öğretim kurumlarına ve gerçek ve tüzel kişilere rehberlik etmek,

b) Bakanlığın görev alanına giren konularda faaliyet gösteren kamu kurum ve kuruluşları, gerçek ve tüzel kişiler ile gönüllü kuruluşlara, faaliyetlerinde yol gösterecek plan ve programlar oluşturmak ve rehberlik etmek,

c) Bakanlık tarafından veya Bakanlığın denetiminde sunulan hizmetlerin kontrol ve denetimini ilgili birimlerle iş birliği içinde yapmak, süreç ve sonuçlarını mevzuata, önceden belirlenmiş amaç ve hedeflere, performans ölçütlerine ve kalite standartlarına göre analiz etmek, karşılaştırmak ve ölçmek, kanıtlara dayalı olarak değerlendirmek, elde edilen sonuçları rapor hâline getirerek ilgili birimlere ve kişilere iletmek,

d) ç) Bakanlık teşkilatı ve personeli ile Bakanlığın denetimi altındaki her türlü kuruluşun faaliyet ve işlemlerine ilişkin olarak, usulsüzlükleri önleyici, eğitici ve rehberlik yaklaşımını ön plana çıkaran bir anlayışla, Bakanlığın görev ve yetkileri çerçevesinde denetim, inceleme ve soruşturma iş ve işlemlerini Bakanlık Maarif Müfettişleri aracilığıla yapmak,

e) Her derece ve türdeki örgün ve yaygın eğitim kurumları ile il ve ilçe millî eğitim müdürlüklerinin rehberlik, işbaşında yetiştirme, denetim, değerlendirme, inceleme, araştırma ve soruşturma hizmetlerini Bakanlık Maarif Müfettişleri aracılığıyla yürütmek,

f) Bakan tarafından verilen diğer görevleri yapmak.

Milli Eğitim Bakanlığı Teftiş Kurulu Başkanlığının yukarıda sayılan görevlerinin oldukça geniş olduğu görülmektedir. Devasa bir yapıya sahip olan Bakanlığın denetlenmesinin, örgütsel devamlılık açısından sahip olduğu önem göz önüne alındığında denetim faaliyetiyle yükümlü olanların yetiştirilmesi ve mesleki yeterlilikleri de ayrıca bir önem taşımaktadır.

\section{Sonuç ve öneriler}

Bu çalışmada Türk Eğitim Sistemi' nin örgütsel yapısının biçimselleşmesi, merkezileşmesi, denetimi ve standardizasyonu açısından incelenmesi yapılmış ve şu bulgulara ulaşılmıştır. 
Eğitim örgütleri insan merkezli örgütler olduğu için aşırı biçimselleştirilmiş kurallar ve prosedürler kabul görmemektedir. Türk milli eğitim sisteminde zaman zaman biçimselleştirmeye yönelik girişimler olsa da süreç içerisinde esnemeler olduğu görülmektedir. Özellikle yönetsel açıdan bakıldığında resmi iş ve işlemlerin belli prosedürler yerine getirilmek suretiyle uygulanmaya başlandığı söylenebilir. Özellikle birçok iş ve işlemin yönetmelik ve yönergelerle düzenlenmeye çalışılması bunun göstergesidir. Örnek vermek gerekirse kurumların resmi yazışmalarda izleyeceği yol ve yöntemler en ince ayrıntısına kadar Bakanlık tarafından belirlenmektedir. Benzer şekilde öğrencilerle ilgili disiplin işleri, sınıf geçme ve devamsızlık işleri gibi birçok konu biçimselleştirilmiş usullerle yerine getirilmektedir.

Bu nedenle merkeziyetçi yapının yüksek düzeyde olması, alt kademedeki işgörenlerin örgütsel konu ve sorunlara ilişkin kendi değerlendirmelerini ortaya koyabilmelerine imkân sağladığı için yapısal bağlamda oluştuğu düşünülen sessizlik olgusunu ortadan kaldıran bir durum olarak değerlendirilmektedir.

Milli eğitim uzmanlığı kadrosunun oluşturulmasıyla Bakanlık çalışmalarında uzmanlaşmaya önem verildiği görülmektedir.

Standartlaşma, belirliliği arttırdığından denetim alanının genişlemesine neden olurken, üstlerin astlarına ayıracakları zamanın miktarını da etkilemektedir. Bu bağlamda denebilir ki standartlaşma derecesine bağlı olarak ast üst sözlü iletişimi olumsuz etkilenmektedir. Zira denetim alanının daralması yöneticilerin iş ve astlara daha fazla zaman ve enerji harcamalarını zorunlu kılmaktadır. Bu durum ilişkilerin sıklaşmasına ve belirli konu ve/ veya sorunlara ilişkin daha fazla istişare yapılması gerekliliğini ortaya çıarmaktadır.

Bir kurumda yetkilendirme yaklaşımının uygulanabilmesi için öncelikle çalışanlar yaptığı işin amaçlarının bilincinde olmalı, ast ve üstlerine inanmalı, kendi yeteneklerinin farkında olmalı ve yetenekleri ile ilgili fırsatları değerlendirebilmelidirler

Milli Eğitim Bakanlığı Teftiş Kurulu Başkanlığının oldukça geniş bir görev alanı olduğu görülmektedir. Devasa bir yapıya sahip olan Bakanl1ğın denetlenmesinin, örgütsel devamlılık açısından sahip olduğu önem göz önüne alındığında denetim faaliyetiyle yükümlü olanların yetiştirilmesi ve mesleki yeterlilikleri de ayrıca bir önem taşımaktadır. 
Eğitim örgütleri insan merkezli örgütler olduğu için aşırı biçimselleştirilmiş kurallar ve prosedürler kabul görmemektedir.Bakanlığa bağlı yürütülen birçok iş ve işlemin yönetmelik ve yönergelerle uygulanmaya çalışılmasının esnetilmesi sorun oluşturmaktadır. Milli eğitim uzmanlığı kadrosunun oluşturulmasıyla Bakanlık çalışmalarında uzmanlaşmaya önem verildiği görülmektedir. Milli Eğitim Bakanlığında standardizasyon çalışmalarına örnek olarak İlköğretim Kurum Standartları Sistemi (IKS) verilebilir. Yetkilendirme okul paydaşlarına, kendi gelişimlerinin sorumluluğunu alabilmelerini, kendi problemlerini çözebilmelerini ve bu sayede özerklik, sorumluluk, seçim ve otorite elde etme olanaklarını sağlamaktadır.Örgütün amaçlarına ne ölçüde ulaştığı, kaynaklarını ne derecede etkili kullanabildiği eğitim-öğretim sürecinin denetlenmesi ve değerlendirilmesi ile olanaklıdır.

\section{Öneriler}

- Eğitim örgütleri insan merkezli örgütler olduğu için aşırı biçimselleştirilmiş kurallar ve prosedürlerden kaçınarak insanı merkeze alan kurallar ve prosedürler oluşturmalıdır.

- Bakanlığa bağlı yürütülen birçok iş ve işlemin yönetmelik ve yönergelerle uygulanmaya çalışılmasının esnetilmesinin yerine daha kapsayıcı mevcut durumun yanı sıra ilerde karşılaşılabilecek durumlar da göz önüne alınarak mevzuat oluşturulmalıdır.

- Milli eğitim uzmanlığı kadrosunun oluşturulmasıyla Bakanlık çalışmalarında uzmanlaşmaya gidilmesi uygulamasının diğer kademelerde de uygulanması yerinde olacaktır.

- İlköğretim Kurum Standartları Sistemi (IKKS)'nin eğitimin diğer kademelerinde de uygulanmasının paydaşların değerlendirmesini öğrenmek ve standardizasyon geliştirmek açısından faydalı olacağ 1 düşünülmektedir.

- Okul paydaşlarına, kendi gelişimlerinin sorumluluğunu alabilmelerini, kendi problemlerini çözebilmelerini ve bu sayede özerklik, sorumluluk, seçim ve otorite elde etmeleri için yetkilendirme yapılmasının gerekli olduğu düşünülmektedir.

- Denetim faaliyetiyle yükümlü olanların yetiştirilmesi ve mesleki yeterliliklerinin artırılması sağlanmalıdır. 


\title{
EXTENDED ABSTRACT
}

\section{Organizational Structure of Turkish Education System: Inspection and Centralization}

\author{
Mustafa Çelikten - Kemal Ayyıldız-Yeliz Yeni Çelikten \\ Erciyes University, Hasan Polatkan Middle School, Keykubat Anatolia High School
}

The current structure of the Turkish education system is based on the regulation that came into force on March 3, 1924, and that all educational institutions in the country should be brought under state control by the Ministry of National Education. With the Law of Tevhid-i Tedrisat dated 1924, which aims to unite education, significant changes have been experienced in the structure and functions of Turkish Educational Organizations (Can and Çelikten, 2000). With this legal regulation called Tevhid-i Tedrisat (teaching union), all educational institutions based on pluralism have been abolished and a state-based education model has been adopted. This model goes further than the idea of state-handed education and prohibits all kinds of educational activities of non-state organizations. In this structure based on centralism, all arrangements are made by the Ministry of National Education and developments in all schools of the country are applied in the same way without considering talent, needs and expectations (Başdemir, 2012).

Since the proclamation of the Republic, the organizational structure of the Turkish Education System has been a structure centralized "management-oriented organizational structure. With the establishment of the Republic, it is seen that all authority in education management is concentrated in the center. Ministry of National Education in the Historical Process: "Ministry of Education" from 1923 to 27 December 1935, "Ministry of Culture" from 28 December 1935 to 21 September 1941, "Deputy Minister of Education" from 22 September 1941 to 9 October 1946, After 10 October 1946, the Ministry of National Education continued its activities under the name of Ministry of Education after 1950 and after 27 May 1960 the Ministry of National Education. While the management levels are short in schools, the management levels of MEB are long. The Minister is at the top 
of the administrative level and directs the Higher Education Council (YÖK), which is directly attached to it, as the directorate and consultancy. The other units are subordinate to the undersecretary, the deputy undersecretary and the deputy minister to the minister. Therefore, a decision of the minister must go a long way to reach the units that are not directly connected to him. Therefore, a decision of the minister must go a long way to reach the units that are not directly connected to him. For example, a decision taken by the minister is sent to the deputy minister, the Organizational Structure of the National Education System and the Ministry of Education Inspectors Sub-Undersecretary, provincial national education directorate, district national education directorate and school directorate and reaches a teacher. In the meantime, the hierarchies in the provincial, district and school directorates should not be ignored. The units other than the provincial and foreign organizations of the Ministry constitute the central organization (Çelikten, 2003; Bozkuş, 2016).

Unification of all educational institutions in Turkey Act (1924) and the Ministry of Education with its current name (MEB) are gathered under the roof. In order to ensure the adaptation of our education system to the developing and changing conditions in the following periods, decree laws, regulations, regulations, directives and circulars were issued. Lastly, the Ministry of National Education Organization Structure was restructured with the Decree Law No. 652 (KHK) published in the Official Gazette dated 14.09.2011. In this way, the units that have lost their functionality have been removed and the units with the same or similar work have been combined and the central organization has become more dynamic (Özkan and Çelikten, 2017).

Thus, unnecessary bureaucracy over the Ministry was reduced and decision-making and implementation processes became faster.

The researches carried out in terms of the formalization, centralization, control and standardization of the organizational structure of the Turkish Education System were reviewed in the literature and the change of the Ministry organization in the historical process was examined. Because education organizations are human-centered organizations, over-stylized rules and procedures are not accepted. It is seen that with the establishment of the national education specialist staff, specialization is given importance in the works of the Ministry. 
An example of the standardization studies in the Ministry of National Education is the Primary School Standards System (IKS). Authorization enables school stakeholders to take responsibility for their own development, solve their own problems, and thus obtain autonomy, responsibility, choice and authority. The extent to which the organization has achieved its objectives and the effective use of its resources is possible through the supervision and evaluation of the educational process. It is considered necessary to authorize school stakeholders to be able to take responsibility for their own development, solve their own problems and thereby obtain autonomy, responsibility, choice and authority.

\section{Kaynakça / References}

Aldemir, M. C. (1985). Örgütler ve yönetimi: makro bir yaklaşım. Ankara:Bilgehan Basımevi.

Alpugan, O., Demir, H., Oktav, M. ve Üner, N. (1997). İşletme ekonomisi ve yönetimi. İstanbul: Beta Basım Yayın

Araç, N. B. (2009). Sinıf öğretmenlerinin örgütsel bağlllık ve yetkilendirilmeye ilişkin görüşleri. Yayınlanmış Yüksek Lisans Tezi, Anadolu Üniversitesi Eğitim Bilimleri Enstitüsü, Eskişehir.

Aydın, İ. (2005). Öğretimde denetim. Ankara: Pegem Akademi.

Aydın, M. (1986). Çă̆gaş eğitim denetimi. Ankara: İM Eğitim Araştırma Yayın Danışmanlık AŞ.

Baransel, A. (1979). Çağdaş yönetim düşüncesinin evrimi: Klasik ve neo-klasik yönetim ve örgüt teorileri. İstanbul: İstanbul Ünv. İşletme Fakültesi Yayınları.

Başaran, İ. E. (2000). Eğitim yönetimi. Ankara: Feryal Matbaası.

Başdemir, H.Y.(2012). Türk eğitim sisteminin yapısal sorunları ve bir öneri. Liberal Düşünce, 17(67), 35-53.

Bozkuş, K.(2016). Örgüt yapısı ve okullar. Kesit Akademi Dergisi (The Journal Of Kesit Academy), 2(4), 236-260.

Bursalığlu, Z. (2000). Okul yönetiminde yeni yapı ve davranış. Ankara: Pegem.

Chatzoglou, P.D., Diamantidis, A. D., Vraimaki, E., Vranakis, S.K. ve Kourtidis, D. A. (2011). Aligning IT, Strategic orientation and organizational structure. Business Process Management Journal, 17(4), 663-687.

Can, N., ve Çelikten, M. (2000). Türkiye'de eğitim yöneticilerinin yetiştirilmesi süreci. Milli Ĕ̆itim Dergisi, 148(8), 43-50. 
Çelikten, M. (2003). Okul kültürünün şekillendirilmesinde müdürün rolleri. Türk Eğitim Bilimleri Dergisi, 1(4), 56-61.

Daft, R. L., Murphy, J., \& Willmott, H. (2010). Organization theory and design. Cengage learning EMEA.

Demirkasimoğlu N. (2011). Türk eğitim sisteminde bir alt sistem olan denetim sisteminin seçilmiş bazı ülkelerin denetim sistemleri ile karşılaştırılması. Abant İzzet Baysal Üniversitesi Sosyal Bilimler Enstitüsü Sosyal Bilimler Enstitüsü Dergisi, 23, 23-48.

Efil, İ. (2002). İsletmelerde yönetim ve organizasyon. Ankara: Alfa Yayınları.

Eren, E. (2000). Örgütsel davranış ve yönetim psikolojisi. İstanbul: Beta Yayın Dağıtım AŞ.

Erdoğmuş, N.(1997). Örgütlerde yetki devrinden personelin güçlendirilmesine geçişte yöneticilerde koçluk (coaching) becerilerinin geliştirilmesi. 21. Yüzyılda Liderlik Sempozyumu Bildiriler Kitabı. Deniz Harp Okulu, İstanbul.

Erserim, A.(2011). yönetim muhasebesi aracı olarak çok boyutlu performans değerleme ve örgüt yapısı ilişkisi üzerine bir araştırma. Aksaray Üniversitesi İktisadi ve İdari Bilimler Fakültesi Dergisi, 3(1), 21-33.

Goyne, J., Padgett, D., Rowicki, M.A., Triplitt, T. (1999). The journey to teacher empowerment. ERIC Document Reproduction Service no. ED 434384.

Hanson, E. M. (1996). Educational administration and organizational behavior, Boston:Allyn and Bacon.

Jones, G. R. (2004). Organizational theory, design and change text and cases. 4th Ed., Upper Saddle River, New Jersey:Pearson/Prentice Hall.

Koçel, T. (2010). Davranışsal (neo-klasik) yönetim ve organizasyon teorisi. işletme yöneticiliğii, (12.Bask1). İçinde (s 231-244), İstanbul: Beta Yayıncıllk.

Lillis, K. M. (1992). Improving basic education: preconditions for successful inspection and supervision-implications for training. International Institute for Educational Planning.

Özkan, H. H. ve Çelikten Y. (2017). Milli eğitim sisteminin örgütsel yapısı ve maarif müfettişleri alt sisteminin işleyişi. OPUS- Uluslararası Toplum Araştırmaları Dergisi, 7(13), 965-990.

Özdemir, B. (2016). Örgütsel yap ve kaynak temelli görüş kapsamında örgütlerde rekabet stratejileri: Türkiye'nin ilk 1000 sanayi kuruluşu'nda bir araştırma. Yayınlanmamış Doktora Tezi, Eskişehir Osmangazi Üniversitesi, Sosyal Bilimler Enstitüsü, Eskişehir. 
Pugh, D. S., D. J. Hickson, C. R. Hinings ve C. Turner. (1968). Dimensions of organization structure. Administrative Science Quarterly. 13(1), 65-105.

Robins, S.P. (1998). Organizational behavior, New Jersey: Prentice-Hall.

Robbins, S. P. ve Judge, T. A. (2013). Organizational behavior. New Jersey:Pirentice Hall.

Sullivan, S., Glanz, J. (2000). Supervision That improves teaching. California: Corwin Press.

Taymaz. H. (1997). Eğitim sisteminde teftiş. Ankara: TAKAV Matbaası.

Tolay, E. (2013). Kamu hizmet örgütleri yönetimi. Ankara: Detay Yayıncllık.

\section{Kaynakça Bilgisi / Citation Information}

Çelikten, M., Ayyıldız, K. ve Yeni-Çelikten, Y. (2019). Türk eğitim sisteminin örgüt yapısı: Denetim ve merkezileşme. OPUS-Uluslararası Toplum Araştırmaları Dergisi , 13(19), 2847-2866. DOI: 10.26466/opus.607124 